\title{
Analisis Gaya Komunikasi Kepemimpinan Kharismatik (Kepemimpinan Dewa Osiris dalam film "God of Egypt")
}

\author{
Widyanilam Rossian, Riris Loisa \\ widyanilam.915150064@stu.untar.ac.id,ririsl@fikom.untar.ac.id
}

Fakultas Ilmu Komunikasi Universitas Tarumanagara

\begin{abstract}
Leaders, roles that have influence in organizations and countries. There is no country without leadership. The leader is the most important element in the country. There are many understandings and concepts about leadership styles, depending on how leaders deepen the concept. Based on the background described earlier, the formulation of the problem to be discussed in this study is What is the style of communication of charismatic leadership ?. This study uses a narrative approach, analyzed by organizational communication theory, leadership style. The research objective to be achieved by the author is to know the communication style of the charismatic leadership of Dewa Osiris in the film "God of Egypt". In this study, the object of the research was the communication style of the charismatic leadership of God Osiris in the film "God of Egypt". Osiris adheres to 2 different communication styles, namely aristocratic communication and egalitarian communication. The two styles of communication continued in the leadership of Osiris as king of Egypt.
\end{abstract}

Keywords: Organization Communication, Communication Style, Charismatic Leadership, Narrative Analysis

\begin{abstract}
Abstrak
Pemimpin, peran yang mempunyai pengaruh dalam organisasi maupun suatu negara. Tidak ada negara tanpa kepemimpinan. Pemimpin adalah elemen paling penting dalam negara. Terdapat banyak sekali pengertian dan konsep mengenai gaya kepemimpinan, tergantung bagaimana pemimpin memperdalam konsep tersebut. Rumusan masalah yang akan dibahas dalam penelitian ini adalah Bagaimana gaya komunikasi kepemimpinan kharismatik?. Penelitian ini menggunakan pendekatan naratif, dianalisis dengan teori komunikasi organisasi, gaya kepemimpinan. Tujuan penelitian yang ingin dicapai oleh penulis adalah mengetahui gaya komunikasi kepemimpinan kharismatik Dewa Osiris dalam film "God of Egypt". Objek penelitian adalah gaya komunikasi kepemimpinan kharismatik Dewa Osiris dalam film "God of Egypt". Osiris menganut 2 gaya komunikasi yang berbeda, yaitu komunikasi aristokrasi dan komunikasi egaliter. Kedua gaya komunikasi tersebut berjalan secara berkesinambungan dalam kepemimpinan Osiris sebagai raja Mesir.
\end{abstract}

Kata kunci: Komunikasi Organisasi, Gaya Komunikasi, Kepemimpinan Kharismatik, Analisis Naratif 


\section{Pendahuluan}

Pemimpin, peran yang mempunyai pengaruh dalam organisasi maupun suatu negara. Tidak ada negara tanpa kepemimpinan. Pemimpin (Pace \& Faules, 2010) adalah elemen paling penting dalam negara. Posisi dan peran pemimpin sangat signifikan dalam menggerakkan roda dalam negara. Ada negara yang stagnan dan tidak berkembang karena faktor kepemimpinan. Sebaliknya, tidak sedikit negara yang berkembang dan maju karena peran kepemimpinan yang efektif.

Gaya kepemimpinan adalah bagaimana seorang pemimpin melaksanakan fungsi kepemimpinannya dan bagaimana pemimpin tersebut dilihat oleh masyarakat yang berusaha dipimpinnya, atau invidu yang mengamati dari luar. Gaya kepemimpinan adalah perilaku dan strategi, yang diterapkan seorang pemimpin dalam mempengaruhi masyarakat ataupun kinerja dan kemajuan suatu negara. (Pace \& Faules, 2010)

Kepemimpinan sudah nyata sejak zaman Mitologi Mesir Kuno. Kepemimpinan yang akan selalu dikenang sebagai zaman keemasan, Kepemimpinan Dewa Osiris. Sebagai Dewa pertama dalam pemerintahan Mitologi Mesir Kuno, Kepemimpinan Osiris merupakan zaman kebahagiaan dalam negeri. "Aku tumbuhan kehidupan”, kata Osiris ketika menjadi pemimpin dalam Mitologi Mesir Kuno (dalam naskah di piramida). Bahwa melalui perkataan tersebut, Osiris ingin menyampaikan bahwa pemimpin adalah sumber kehidupan bagi rakyatnya. Dewa Osiris yang kini dipuja sebagai dewa panen dan kesuburan pada musim panas di Mesir selalu ditunggu-tunggu setiap setiap tahun di Timur Orion. Kepemimpinan Dewa Osiris dalam penelitian ini akan dikupas dari film "God of Egypt" (2016). (Black, 2007).

\section{Metode Penelitian}

Komunikasi merupakan salah satu aspek terpenting namun juga kompleks dalam kehidupan manusia. Manusia sangat dipengaruhi oleh komunikasi yang dilakukannya dengan manusia lain, baik yang sudah dikenal maupun yang tidak dikenal sama sekali (Morissan, 2013).

Komunikasi dalam organisasi (Soetopo, 2012) merupakan proses penghasilan, penyaluran, dan menerima pesan-pesan dalam keseluruhan proses organisasi. Dalam komunikasi, kemampuan komunikator, keakuratan pesan, proses pengendalian, ketetapan saluran dan menerima pesan merupakan komponen yang sangat penting. Terganggunya semua komponen itu akan membawa komunikasi tidak dapat berjalan dengan semestinya.

Kepemimpinan adalah faktor penting dalam suatu organisasi. Menurut Stogdill (1974), "kepemimpinan adalah konsep manajemen yang dirumuskan dalam berbagai macam definisi tergantung dari mana titik pandang."

Menurut Martinis Yamin dan Maisah (dalam Wirawan 2013) Kepemimpinan adalah suatu proses mempengaruhi yang dilakukan seseorang dalam mengelola anggota kelompoknya untuk mencapai tujuan organisasi.

Rivai (2014) mengemukakan bahwa gaya kepemimpinan merupakan norma perilaku yang digunakan oleh seseorang pada saat orang tersebut mencoba mempengaruhi perilaku orang seperti yang ia lihat. Nasution mengemukakan bahwa seorang pemimpin harus mengembangkan suatu gaya dalam memimpin bawahannya. Suatu gaya kepemimpinan dapat dirumuskan sebagai suatu pola perilaku yang dibentuk untuk diselaraskan dengan kepentingan-kepentingan organisasi dan karyawan untuk dapat mencapai tujuan yang telah ditetapkan. 
Gaya kepemimpinan menurut Sutikno (2014), gaya kepemimpinan atau perilaku kepemimpinan atau sering disebut Tipe Kepemimpinan. Tipe kepemimpinan yang luas dikenal dan diakui keberadaanya adalah Tipe Otokratik, Tipe Kendali Bebas atau Masa Bodo (Laisezz Faire), Tipe Paternalistik, Tipe Kharismatik, Tipe Militeristik, Tipe Pseudo-Demokratik, dan Tipe Demokratik. Dalam penelitian ini akan dibahas lebih dalam mengenai:

Gaya atau kepemimpinan kharismatik ini bersandar pada karaktersitik kualitas kepribadian yang istimewa sehingga mampu menciptakan kepengikutan pada pemimpinan sebagai panutan, yang memiliki daya tarik yang sangat memukau, dengan memperoleh pengikut yang banyak (sangat besar) jumlahnya. Kepemimpinan kharismatik dapat diartikan juga sebagai kepemimpinan yang memiliki kekuasaan yang kuat dan tetap serta dipercayai oleh pengikut-pengikutnya.

Penelitian analisis naratif mempunyai struktur, yaitu cerita (story) dan alur (plot). Story adalah peristiwa yang utuh, yang sesungguhnya, dari awal hingga akhir. Story merupakan urutan kronologis dari suatu peristiwa, di mana peristiwa tersebut bias ditampillan dalam teks bisa juga tidak ditampilkan dalam teks. Sementara plot adalah peristiwa yang secara eksplisit ditampilkan dalam suatu teks dan urutan peristiwa dapat dibolak-balik.

\section{Hasil Temuan dan Diskusi}

Tabel 2. Analisis Karakter Kunci Vladimir Propp

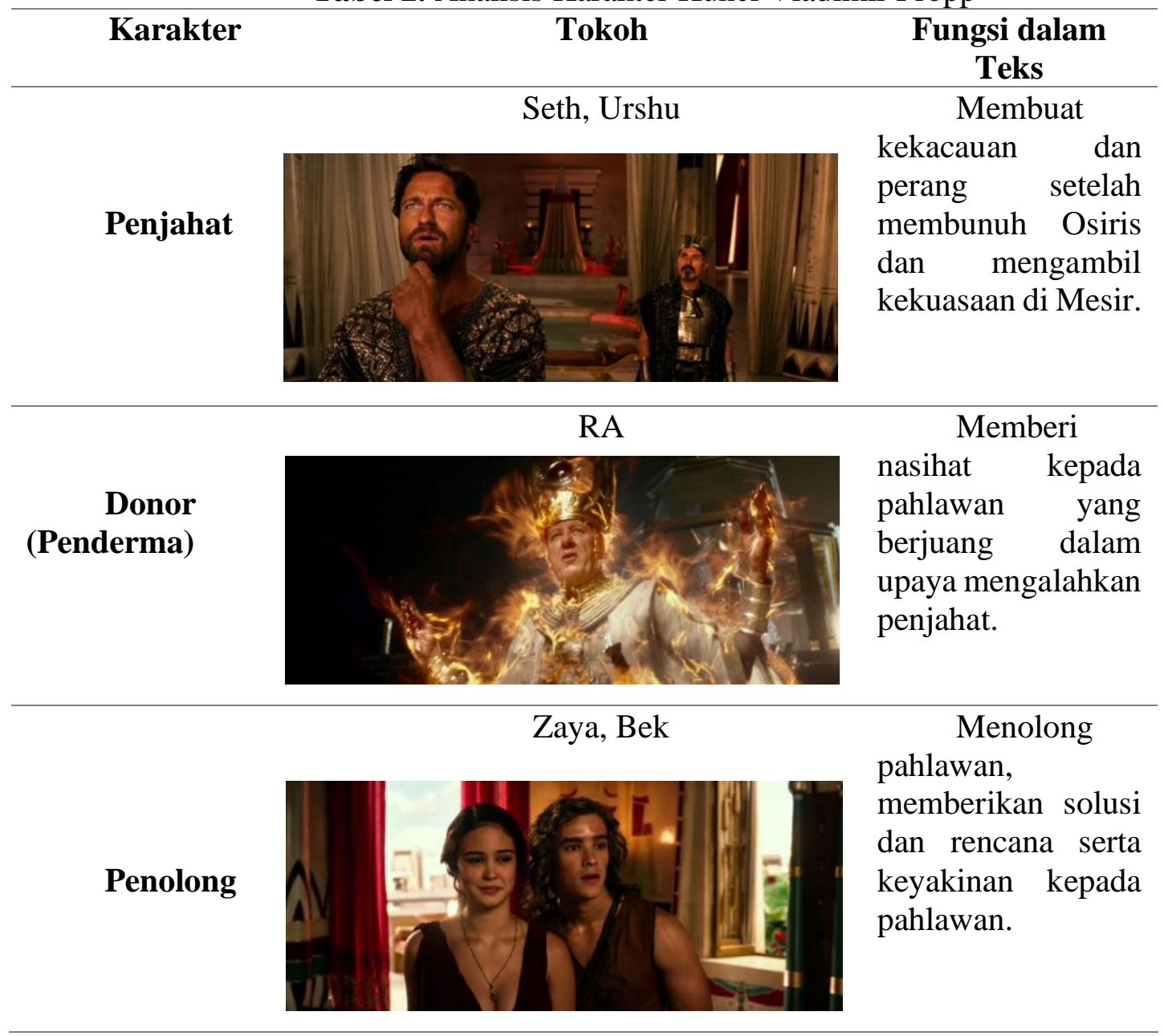




Putri
Pencintai yang
pahlawan, dan
kemudian dijadikan
Ratu Mesir oleh
penjahat.

(Sumber : Olah data dengan kutipan film)

Tabel 3. Analisis Alur (Plot) Film God of Egypt

\section{Gaya Kepemimpinan Kharismatik}

Kualitas kepribadian yang istimewa1 sehingga mampu menciptakan kepengikutan pada pemimpinan sebagai panutan, yang memiliki daya tarik2 yang sangat memukau, dengan memperoleh pengikut yang banyaks (sangat besar) jumlahnya. Kepemimpinan kharismatik dapat diartikan sebagai kemampuan mempengaruhi orang lain dengan mendayagunakan keistimewaan atau kelebihan dalam sifat/aspek kepribadian pemimpin, sehingga menimbulkan rasa hormat, rasa segan4 dan kepatuhan yang tinggi pada para pengikutnya.

\begin{aligned} & No. \multicolumn{2}{c}{ Analisis } \\ & 1. Pemimpin $\begin{array}{l}\text { Pipandang } \\ \text { istimewa karena sifat-sifat } \\ \text { kepribadiannya } \\ \text { mengagumkan dan berwibawa. } \\ \text { Kepribadian yang istimewa } \\ \text { adalah kepribadian yang rendah } \\ \text { hati, adil, dermawan dan } \\ \text { bijaksana. }\end{array} \\ &$ Plot 1.1 Osiris Berpidato \end{aligned}




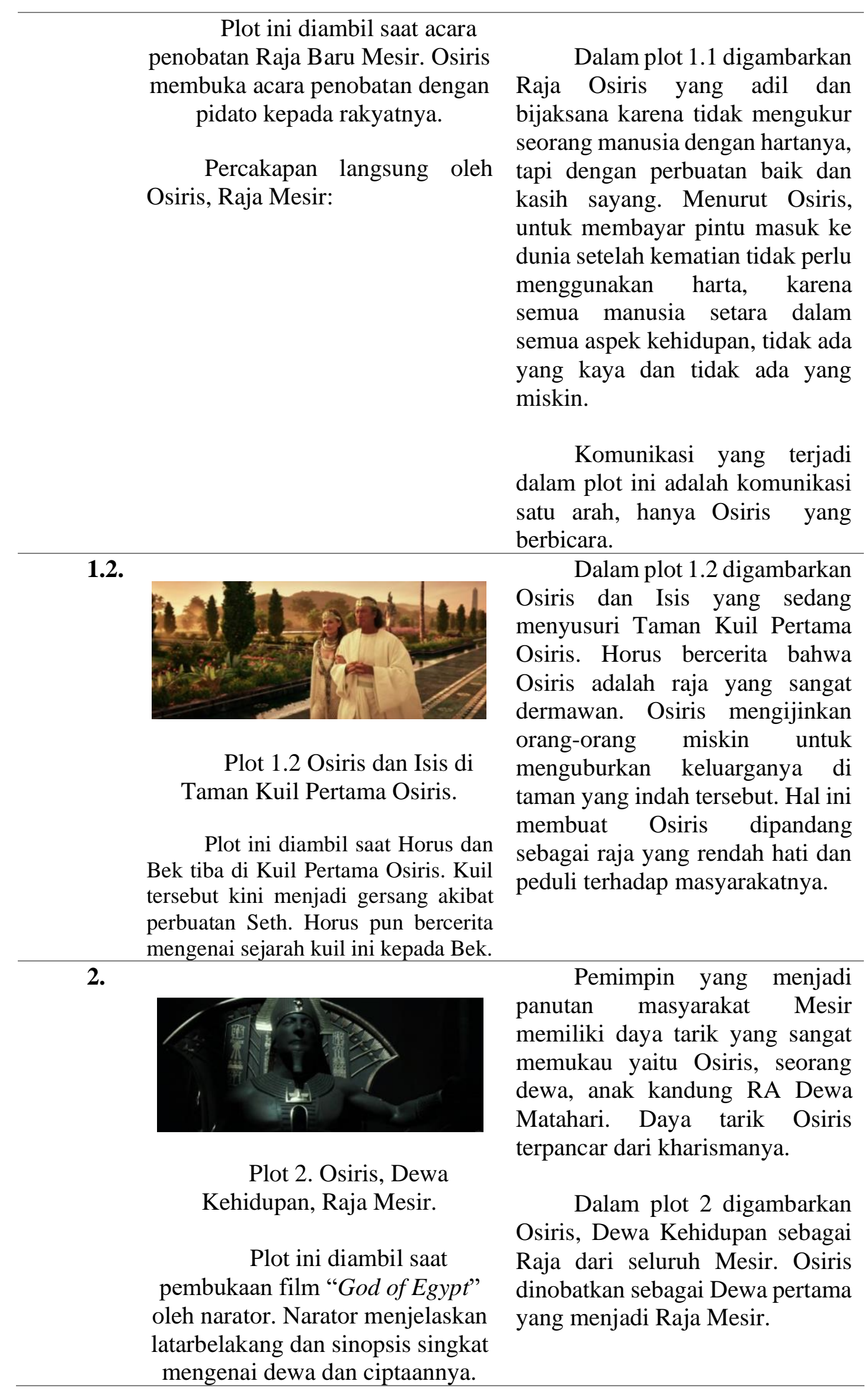




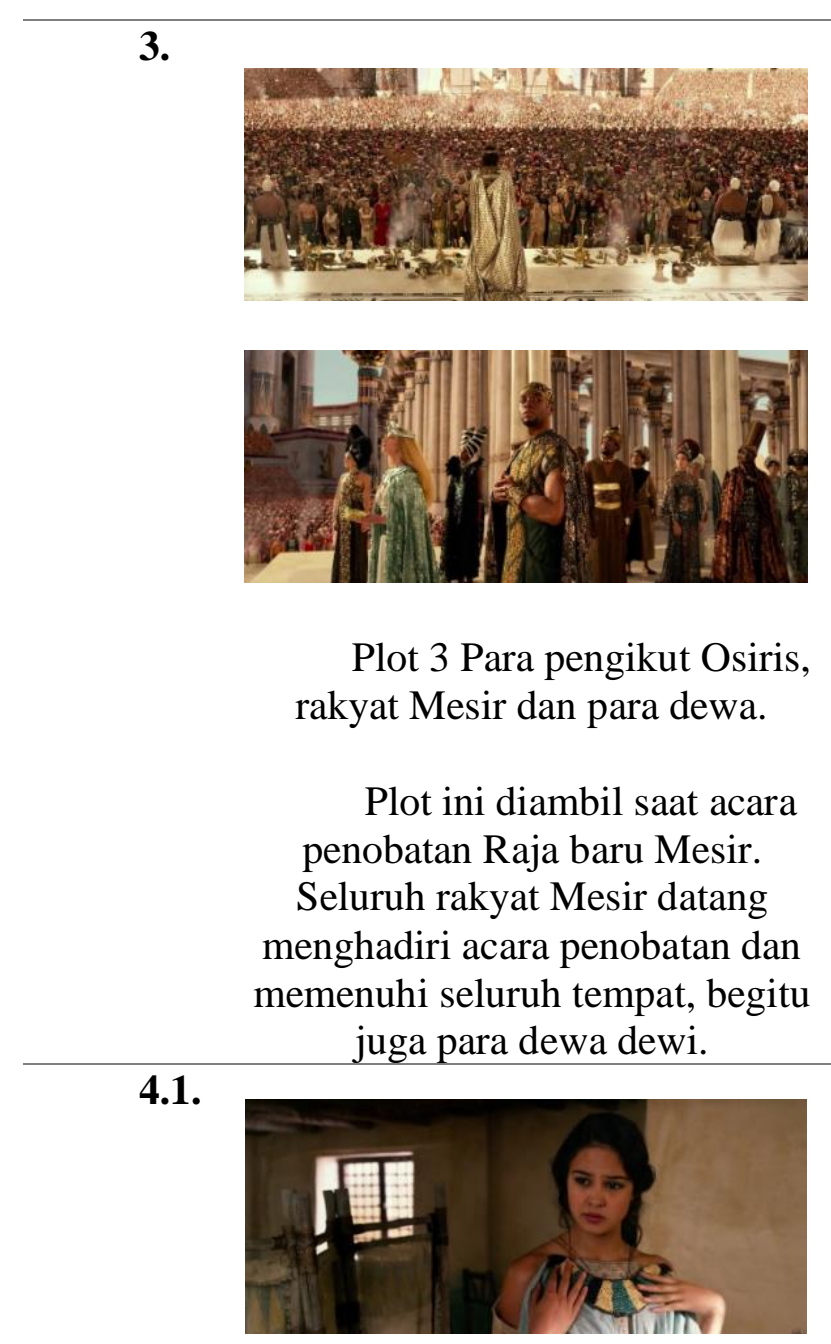

Plot 4.1. Zaya mencoba pakaiannya untuk dipakai di acara penobatan.

Plot ini diambil saat Zaya mencoba berbagai pakaiannya. Zaya merasa pakaiannya tidak ada yang pantas untuk diperlihatkan kepada Raja Osiris.

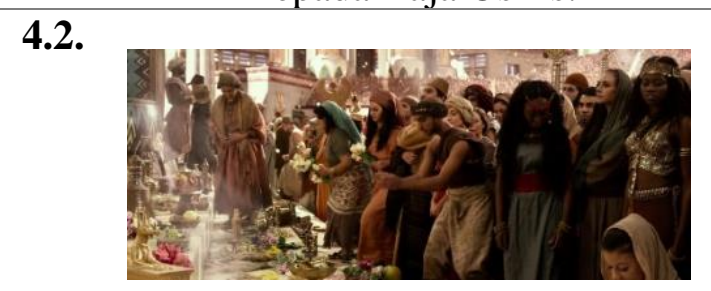

Plot 4.2. Masyarakat Mesir memberikan persembahan kepada Raja Osiris di acara penobatan.
Kepemimpinan Osiris yang Kharismatik mampu mempengaruhi banyak orang (masyarakat) sehingga Osiris memperoleh pengikut yang banyak (sangat besar jumlahnya). Tidak hanya rakyat, namun dewadewa yang lainnya turut menjadi pengikut Osiris.

Dalam plot 3 digambarkan para pengikut Osiris yang merupakan rakyat Mesir dan para dewa dewi Mesir.
Kepemimpinan Osiris yang
Kharismatik menimbulkan rasa
hormat, rasa segan dan kepatuhan
yang tinggi pada para
pengikutnya.

Dalam plot 4.1 digambarkan Zaya yang ingin pergi ke acara penobatan dengan pakaian terbaiknya untuk menunjukkan rasa hormat dan rasa segan yang tinggi terhadap Raja Osiris. Menurut Zaya pakaian biasa tidak layak untuk diperlihatkan kepada sang raja.

Dalam plot 4.2 digambarkan masyarakat Mesir melakukan penghormatan kepada Raja Osiris dengan memberikan persembahan berupa gandum, bunga, perhiasan, dan emas.

(Sumber : Olah data dengan kutipan film) 
Widyanilam Rossian, Riris Loisa: Analisis Komunikasi Kepemimpinan Kharismatik (Kepemimpinan Dewa Osiris dalam film "God of Egypt”)

\section{a. Komunikasi Organisasi}

Hubungan teori komunikasi organisasi terhadap penelitian ini adalah komunikasi organisasi dalam negara Mesir yang terjadi antara Raja Osiris dengan masyarakat Mesir. Komunikasi organisasi yang terjadi yaitu Raja Osiris sebagai pemimpin negara Mesir dengan masyarakat Mesir sebagai pengikut. Dalam film ini tidak terdapat komunikasi langsung antara Osiris dengan masyarakat, namun terlihat bahwa terjadi komunikasi antara kedua pihak. Dalam hal ini, penulis menganalisis bahwa Osiris adalah tokoh pemimpin yang menjaga jarak dalam komunikasi langsung (tatap muka) dengan rakyat. Gaya komunikasi Osiris adalah komunikasi Aristokrasi.

Aristokrasi berasal dari kata Yunani yang berarti kekuatan hebat. Aristokrasi adalah bentuk pemerintahan yang dipegang olek kelompok kecil yang mendapat keistimewaan, atau kelas yang berkuasa. Dengan adanya kekuatan oleh sekelompok istimewa, maka terjadinya pola komunikasi yang berbeda. Kelompok istimewa ini perlu menjaga jarak dengan kelompok lain diluar kelompoknya, sehingga kelompok menjaga jarak dalam hal berkomunikasi. Dalam film, terdapat sekelompok istimewa yaitu kelompok/golongan para dewa dan dewi. Osiris sebagai bagian dalam kelompok tersebut menjaga komunikasi dengan para rakyatnya. Hal ini dapat disimpulkan Osiris yang menjaga wibawa dan kharismanya sebagai seorang raja. Namun Osiris tetap menjaga komunikasi dengan rakyatnya, dengan mediator atau doa dan persembahan masyarakat kepadanya.

Pada pidato di acara penobatan, Osiris mengatakan bahwa semua masyarakat setara dalam semua aspek. Dalam hal ini, penulis menganalisis bahwa gaya komunikasi Osiris adalah komunikasi egaliter. Egalitarianisme berasal dari kata Prancis yang berarti sama. Egalitarianisme adalah pemikiran bahwa pada hakikatnya semua manusia sama dalam status, nilai, dan moral. Komunikasi egaliter terjadi karena Osiris menganggap bahwa dirinya dan semua manusia adalah ciptaan yang tidak sempurna. Walaupun Osiris merupakan bagian dari kelompok istimewa, namun takdir seluruh makhluk hidup ada di tangan pencipta. Tidak ada makhluk yang abadi, termasuk para dewa, pada saatnya mereka akan meninggalkan dunia ini dan menuju ke dunia setelah kematian.

Osiris menganut 2 gaya komunikasi yang berbeda, yaitu komunikasi aristokrasi dan komunikasi egaliter. Kedua gaya komunikasi tersebut berjalan secara berkesinambungan dalam kepemimpinan Osiris sebagai raja Mesir. Satu sisi, Osiris adalah dewa yang mempunyai kekuatan dan kekuasaan yang hebat sehingga membatasi komunikasi dan interaksi dengan rakyatnya untuk menjaga wibawa dan kharismanya sebagai seorang raja. Di sisi lainnya, Osiris merupakan ciptaan Dewa RA, sama dan setara dengan ciptaan lainnya. Dewa RA berkata "Mereka (Osiris dan Seth) adalah anakku. Mereka berdua setara dengan dimataku, seperti semua ciptaanku.”. Dalam kepemimpinannya, Osiris mengatur komunikasi yang sesuai dengan situasi dalam berinteraksi dan berkomunikasi dengan rakyatnya. Ada saat Osiris berkomunikasi dengan gaya komunikasi aristokrasi, dan ada saatnya pula bagi Osiris berkomunikasi dengan gaya komunikasi egaliter.

Osiris harus menjaga wibawa dan kharismanya sebagai seorang raja, namun ia tetap rendah hati dan berbuat baik kepada masyarakat karena Osiris sadar akan kesetaraan semua makhluk hidup di mata pencipta.

\section{b. Kepemimpinan}

Hubungan teori Kepemimpinan terhadap penelitian ini adalah kepemimpinan Raja Osiris sebagai Raja Mesir. Dalam film "God of Egypt", terlihat bahwa 
kepemimpinan Osiris disukai dan dikagumi oleh masyarakat. Kepemimpinan Osiris mampu mempengaruhi masyarakat Mesir, memahami dan mengikuti hal yang menjadi kebijakan di Mesir, seperti menyembah para dewa-dewi terutama Dewa RA (sebagai pencipta alam semesta) dan Osiris sebagai Raja. Berbagai kebijakan pun diterima dengan senang hati oleh masyarakat Mesir seperti pemberlakuan warisan terhadap penetapan pintu gerbang terakhir pada dunia setelah kematian.

Kepemimpinan sangat menentukan keberlangsungan dan kehidupan negara Mesir. Pembunuhan Osiris dan pengalihkan kekuasaan terhadap Seth membuat negara Mesir terpuruk dan menderita. Kepemimpinan Seth yang kejam membawa masyarakat ke arah yang buruk, seperti memperkerjakan masyarakat sebagai budak hingga mereka meninggal. Hal ini membuat pemakaman di Mesir meluas, bahkan dewa dan dewi yang mencoba untuk menolong tidak dapat berbuat apa-apa selain menghadapi kematiannya. Kepemimpinan Seth yang egois dan serakah akan kekuasaan bahkan mengarahkan Mesir kepada kiamat. Menurut Seth dengan kiamat, ia dapat membentuk ulang ciptaannya, termasuk para dewa dan dewi. Seth ingin tetap hidup selamanya. Komunikasi yang terjadi dalam pemerintahan Seth hanyalah perintah (komunikasi satu arah), sehingga tidak ada pertukaran pendapat. Bahkan beberapa perintah Seth tidak dijalankan oleh masyarakat, dewa dan dewi, sehingga Seth menghukum mereka dengan kematian.

Kepemimpinan Seth berbeda sekali dengan kepemimpinan Osiris yang penuh dengan rasa kepeduliaan, mengajarkan masyarakat untuk rendah hati dan melakukan perbuatan baik. Masyarakat sangat mencintai Osiris sebagai pemimpin mereka. Dengan segala kemurahan hati Osiris, Mesir tumbuh sebagai negara yang hebat, penuh harapan akan kehidupan yang lebih baik bagi setiap rakyatnya di dunia setelah kematian. Komunikasi yang terjadi saat menjalankan pemerintahan sangatlah penting. Sebagai pemimpin, Osiris mendengarkan keluhan rakyat, peduli dan mengayomi sehingga masyarakat damai dan sejahtera.

\section{c. Gaya Kepemimpinan Kharismatik}

Gaya atau kepemimpinan kharismatik ini bersandar pada karaktersitik kualitas kepribadian yang istimewa sehingga mampu menciptakan kepengikutan pada pemimpinan sebagai panutan, yang memiliki daya tarik yang sangat memukau, dengan memperoleh pengikut yang banyak (sangat besar) jumlahnya.

Hubungan teori Gaya Kepemimpinan Kharismatik terhadap penelitian ini adalah Raja Osiris menggunakan Gaya Kepemimpinan Kharismatik.

Gaya Kepemimpinan Kharismatik Osiris memiliki kebutuhan kuat akan kekuasaan (sebagai pemimpin untuk menggerakkan masyarakat dalam mencapai tujuan akhir hidupnya), memiliki percaya diri yang tinggi (sebagai dewa pertama yang menduduki tahta kerjaan Mesir), dan pendirian yang kuat dalam mewujudkan kepercayaan dan idealitasnya (sebagai pemimpin yang tegar dan kukuh dalam memimpin negerinya agar terus berkembang).

Dewa Osiris sebagai pemimpin kharismatik sangat dicintai dan disayangi oleh masyarakatnya. Osiris dipandang istimewa karena sifat-sifat kepribadiannya yang mengagumkan dan berwibawa. Kepribadian yang istimewa adalah kepribadian yang rendah hati, adil, dermawan dan bijaksana. 
Widyanilam Rossian, Riris Loisa: Analisis Komunikasi Kepemimpinan Kharismatik (Kepemimpinan Dewa Osiris dalam film "God of Egypt”)

\section{Simpulan}

Berdasarkan hasil penelitian tentang analisis gaya komunikasi kepemimpinan kharismatik Dewa Osiris dalam film "God of Egypt" maka diambil kesimpulan:

Osiris menganut dua gaya komunikasi yang berbeda, yaitu komunikasi aristokrasi dan komunikasi egaliter. Kedua gaya komunikasi tersebut berjalan secara berkesinambungan dalam kepemimpinan Osiris sebagai Raja Mesir. Di satu sisi, Osiris adalah dewa yang mempunyai kekuatan dan kekuasaan yang hebat sehingga membatasi komunikasi dan interaksi dengan rakyatnya untuk menjaga wibawa dan kharismanya sebagai seorang raja. Di sisi lainnya, Osiris merupakan ciptaan Dewa RA, sama dan setara dengan ciptaan lainnya.

Dewa Osiris sebagai pemimpin kharismatik sangat dicintai dan disayangi oleh masyarakatnya. Osiris dipandang istimewa karena sifat-sifat kepribadiannya yang mengagumkan dan berwibawa. Kepribadian yang istimewa adalah kepribadian yang rendah hati, adil, dermawan dan bijaksana.

\section{Ucapan Terima Kasih}

Terima kasih kepada dosen pembimbing serta rekan-rekan diskusi di Fakultas Ilmu Komunikasi.

\section{Daftar Pustaka}

Ardianto, Elvinaro. (2014). Metodelogi Penelitian untuk Public Relations Kuantitatif dan Kualitatif. Bandung: Simbiosa Rekatama Media

Black, Jonathan. (2007). The Secret History of the World. Jakarta: PT. Pustaka Alvabert

Bungin, M. Burhan. (2008). Penelitian Kualitatif; Komunikasi, Ekonomi, Kebijakan Publik, dan Ilmu Sosial Lainnya. Jakarta: Kencana

D. Ruben, Brent And Lea P Steward. (1998) Comunication And Human Behavior. USA: Allyn And Bacon

Daft, Richard L. (2007). The Leadership Experience Fourth Edition.

Eriyanto. (2013). Analisis Naratif: Dasar-dasar Penerapan dalam Analisis Teks Berita Media. Jakarta: Kencana Prenada Media Grup

Gahlin, Lucia. (2014). Egypt: Gods, Myths, and Religion. London: Annes Publishing https://bbfc.co.uk/releases/gods-egypt-film

https://web.archive.org/web/20151203022231/http://www.godsofegypt.movie/story

https://www.kompasiana.com/melinanurins8/580cea24927e611c2a8c4b3f/krisiskepemimpinan-di-indonesia

J. R. Raco. (2010). Metode Penelitian Kualitatif Jenis, Karakteristik dan Keunggulannya. Jakarta: PT Gramedia Widiasarana Indonesia

Mohammad, Nazir. (2011). Metode Penelitian. Jakarta: Ghalia Indonesia.

Moleong, Lexy J. (2007). Metode Penelitian Kualitatif. Bandung: Remaja Rosdakarya.

Morissan. (2013). Teori Komunikasi: Individu hingga Massa. Jakarta: Kencana

Muhammad, Arni. (2011). Komunikasi Organisasi. Jakarta: PT. Bumi Aksara

Mulyana, Deddy. (2005). Ilmu Komunikasi Suatu Pengantar. Bandung: Remaja Rosdakarya 
Nurjaman, Kadar dan Umam, Khaerul. (2012). Komunikasi dan Public Relations. Bandung:Pustaka Setia.

Pace, R. Wayne dan Faules, Don F. (2010). Komunikasi Organisasi: Strategi Meningkatkan Kinerja Perusahaan. Bandung. PT Remaja Rosdakarya

Pratista, Himawan. (2008). Memahami Film. Yogjakarta: Homerian Pustaka

Richard, Arneson. (2002). "Egalitarianism", The Stanford Encyclopedia of Philosophy. London

Rivai, Veithzal. (2014). Kepemimpinan dan Perilaku. Jakarta: PT Raja Grafindo Persada

Shaw, Garry. (2012). The Pharaoh: Life at Court and on Campaign. New York: Thames \& Hudson

Soetopo, Hendyat. (2012). Perilaku Organisasi. Bandung: PT. Remaja Rosdakarya

Stogdill, Ralph. (1974). Handbook of Leadership. New York: The Free Press

Sugiyono. (2011). Metode Penelitian Kuantitatif, Kualitatif dan R\&D. Bandung: Alfabeta

Sutikno, Sobry M. (2014). Pemimpin dan Gaya Kepemimpinan. Lombok: Holistica

Suyitno. (2018). Metode Penelitian Kualitatif: Konsep, Prinsip dan Operasionalnya. Tulungagung: Akademia Pustaka

Wasson, Ellis. (2006). Aristocracy in the Modern World. London: Palgrave Macmillan

West, Richard \& Lynn H Turner. (2008). Pengantar Teori Komunikasi. Edisi 3. Jakarta: Salemba Humanika

Wirawan (2013). Kepemimpinan : Teori, Psikologi, Perilaku Organisasi, Aplikasi dan Penelitian. Jakarta: PT Raja Grafindo Persada 